Pak. J. Agri. Sci., Vol. 55(2), 381-387; 2018

ISSN (Print) 0552-9034, ISSN (Online) 2076-0906

DOI: $10.21162 / P A K J A S / 18.5017$

http://www.pakjas.com.pk

\title{
FECUNDITY AND BODY SIZE-FECUNDITY RELATIONS OF Palaeolecanium bituberculatum (Targ. and Tozz.) (Hemiptera: Coccidae) ON APPLE TREES
}

\author{
Ekrem Ogur ${ }^{1}$, and Celal Tuncer ${ }^{2}$
}

\author{
${ }^{1}$ Selcuk University, Faculty of Agriculture, Department of Plant Protection, Konya 42250, Turkey; ${ }^{2}$ Ondokuz Mayıs \\ University, Faculty of Agriculture, Department of Plant Protection, Samsun 55139, Turkey \\ Corresponding author's e-mail: ekremogur@selcuk.edu.tr
}

\begin{abstract}
This study was carried out on four apple cultivars including Ambassy, Cevaal, Golden and Topred in Konya province in 20072008. Fecundity, the relations between the body size-fecundity, body size-egg size and population density-fecundity of Bituberculate scale (Palaeolecanium bituberculatum (Targ. and Tozz.) (Homoptera: Coccidae)) were investigated. Fifty females were collected from each apple cultivar and fecundity and female body scale dimensions were determined for each female separately. Also population densities on each cultivar and egg size of different females were measured. Average fecundity of Ambassy, Cevaal, Golden and Topred cultivars was respectively observed as 897 (285-1730), 956 (317-1622), 613 (136-1257) and 761 (186-1254) eggs. When data from all apple cultivars regressed together, the correlation coefficient for the body height, length and width - fecundity was calculated as $\mathrm{r}^{2}=0.73, \mathrm{r}^{2}=0.63$ and $\mathrm{r}^{2}=0.62$, respectively. Multiple regression of female scale width, length, height and fecundity yielded the highest coefficient $\left(\mathrm{r}^{2}=0.83\right)$. The degree of regression between body dimensions and fecundity varied based on cultivars and separate assessments for each cultivar yielded better outcomes than combined assessments. The correlation coefficient between population density-fecundity was $r^{2}=0.831$, but the relation was not significant because of low sample size $(F(1,2)=9.852, p=0.088)$. There weren't any significant relations between fecundity-egg size and between female scale size-egg size of bituberculate scale.
\end{abstract}

Keywords: Apple, bituberculate scale, body size, egg size, fecundity, Palaeolecanium bituberculatum

\section{INTRODUCTION}

Bituberculate scale, Palaeolecanium bituberculatum (Targ. and Tozz.) (Hemiptera: Coccidae), which has a wide distribution in Czech Republic, Poland, Germany, France, Russia, Yugoslavia, Romania, Hungary, Italy, Denmark, England, Holland, Sweden, Afghanistan, Iran, N. Africa and Turkey, is a common Palearctic species (Kosztarab and Kozar, 1988). The nymphs of the Bituberculate scale, which gives one generation per year, generally feed on leaves and adults on thin branches, overwinters in egg stage, nymphs disperse on leaves after the blooming period, females migrate to branches at the end of June and start egg laying beneath the scale from August to the end of October and each female lays 283-1003 eggs (Kosztarab and Kozar, 1988). Palaeolecanium bituberculatum is an economically important pest on pome and stone fruits and all Rosaceae (except Juglans and Corylus genera) species are among the host of this pest, the most important damages are seen on apple trees (Kozar et al., 1979; Lodos, 1986; Okul et al., 1987; Kosztarab and Kozar, 1988; Anonymous, 1995). The large population of the pest cause damage by feeding on plant sap, reducing vigour, producing chlorotic areas on leaves, premature leaf drop, killing the shoots and branches and ultimately leading to decrease both in quality and quantity of the fruit. There is less honeydew production in Bituberculate scale compared to other scale insects (Lodos, 1986; Anonymous, 1995; Tuncer and Ogur, 2009).

Even though $P$. bituberculatum is widespread in Turkey, there have been quite a few studies on this pest and most of them are systematicals and faunisticals (İren and Okul, 1974; Kozar et al., 1979; Yigit and Uygun, 1982; Okul et al., 1987; Ozgokçe, 1995; Ozgökçe and Yaşar, 1995; Erol and Yaşar, 1996 \& 1999; Ozgokçe et al., 1999; Ulgenturk and Çanakçıoglu, 2004; Vuruş and Erler, 2004; Zeki et al., 2004; Kaydan et al., 2007). Furthermore, when international literature is surveyed, it is found that there is limited number of research on this pest.

The relationship between fecundity and body size has been well known in insects (Honek, 1993). There were lots of studies about the relations between population density and fecundity, population density and egg number, body size and fecundity of scale insects on different plant varieties (Speight, 1994; Lo, 1995; Loch and Zalucki, 1997; Wakgari and Giliomee, 1999). The body size and fecundity of an insect are one of the important criteria expressing the sensitivity or resistance of plants to that insect. Another sign indicating plant resistance against insects is the occurrence of small adults with low reproductive capacity (Pedigo, 1996). This relationship can also provide a quick and easy tool to estimate the fecundity of many pests. Many scale insects lay their eggs 
beneath the body of female scale and these eggs must be counted individually to determine the fecundity.

The aim of the present study was to investigate the fecundity, the relations between population density-fecundity, the female body size (length, width, height)-fecundity and number of eggs-egg size of Bituberculate scale on four apple varieties.

\section{MATERIALS AND METHODS}

The Bituberculate scales were collected from four apple cultivars organically grown in Sarayönü town of Konya province, Turkey. Experimental orchard has a size about 3600 $\mathrm{m}^{2}$, and located at $1076 \mathrm{~m}$ elevation. The orchard is composed of four apple cultivars (Ambassy, Cevaal, Golden and Topred) on 1250 trees. The dwarf apple trees were six years old and grafted on M9 rootstocks. A stereomicroscope (Olympus SZ61) and ocular micrometer (Olympus, $0.01 \mathrm{~mm}$ ) was used to measure the egg sizes (width, length), a digital caliper (Mitutoyo, CD-15CPX) was used to measure the body size of adult female scale insects.

The 2-3 years old infested branches were cut with pruning scissors, labeled, put into plastic bags and taken to the laboratory in February. From each apple cultivar, 50 females and a total of 200 females which were dead and full of eggs beneath their scales were sampled randomly. The scale of the female was removed gently and eggs were put in $9 \mathrm{~cm}$ diameter petri dishes. Afterwards, size of the scale of the female (width, length, height) was measured by a digital caliper $( \pm 1 \%)$. Eggs of each female were counted individually under a stereomicroscope with the aid of a brush and number of eggs was recorded. This was repeated for 50 female scales in each apple cultivar and average fecundity was determined. In order to determine the relation between body sizefecundity, regression analysis was performed on resultant data of 200 females (number of eggs, body size (width, length, height)). The regression between fecundity and each body size were analyzed separately to determine which body size is more closely related with fecundity. In addition, multiple regression analyses were conducted to examine the relationship between fecundity and three body measurements (width, length and height). Fecundity was considered as dependent and body measurements as independent variables. Two branches (20 cm long) at 0-2 m height of tree canopy and each of four cardinal directions of 10 trees from each of four apple cultivars were sampled randomly and population density was estimated on the basis of the number of the scales. The number of eggs of 50 adult females which were chosen randomly from these branches for each apple cultivar was determined. The relation between population densityfecundity was analyzed by regression.

In order to determine if there was a significant difference in egg sizes (width, length) of females which laid different number of eggs, 5 females which were dead, full of eggs beneath their scales and the number of eggs ranged 200-1400 from each apple cultivar (totally 20 females) were selected. They were selected from among the females of previous trial that their number of eggs were determined under a stereomicroscope. After that, width and length of the 20 eggs (totally 20x20=400 eggs) which were selected randomly from each female were measured. Regression analyses were conducted to determine if there was a relationship between fecundity and egg size. All statistical analyses were carried out with SPSS 16.0 and means were compared by using Tukey test.

\section{RESULTS}

Fecundity and body size of $P$. bituberculatum: The average fecundity on Ambassy, Cevaal, Golden and Topred apple cultivars were respectively observed as 897.98 \pm 49.23 ; $956.34 \pm 51.44 ; 613.22 \pm 35.79$ and $761.44 \pm 38.57$ eggs on apple cultivars aforementioned respectively. Accordingly, the highest number of eggs were observed on Cevaal, and the least on Golden cultivars. Regardless of the apple cultivar, the result of the measurement conducted in 200 females showed that a female laid an average of 807.25 \pm 23.89 eggs (ranged from 136 to1730) (Figure 1).

Although the differences between fecundity in Cevaal and Ambassy were not significant $(\mathrm{P}>0.05)$, it was found that they were significantly different from Topred and Golden

Table 1. Population density, fecundity and mean values of female body size of Palaeolecanium bituberculatum on different apple cultivars (mean $\pm \mathrm{SE}, \mathrm{n}=\mathbf{5 0}$ for each cultivar).

\begin{tabular}{|c|c|c|c|c|c|c|c|}
\hline \multirow[t]{2}{*}{ Apple cultivar } & \multirow[t]{2}{*}{ Population density } & \multicolumn{3}{|c|}{ Fecundity } & \multicolumn{3}{|c|}{ Mean values of female body size (mm) } \\
\hline & & Mean & Min. & Max. & Width & Length & Height \\
\hline Ambassy & $12.03 \pm 0.87 \mathrm{AB}$ & $897.98 \pm 49.23 \mathrm{~A}$ & 285 & 1730 & $4.68 \pm 0.07 \mathrm{~B}$ & $5.85 \pm 0.09 \mathrm{~B}$ & $3.10 \pm 0.07 \mathrm{~B}$ \\
\hline Cevaal & $6.38 \pm 0.33 \mathrm{~B}$ & $956.34 \pm 51.44 \mathrm{~A}$ & 317 & 1622 & $4.98 \pm 0.06 \mathrm{~A}$ & $6.16 \pm 0.09 \mathrm{~A}$ & $3.34 \pm 0.06 \mathrm{~A}$ \\
\hline Golden & $16.51 \pm 0.94 \mathrm{~A}$ & $613.22 \pm 35.79 \mathrm{C}$ & 136 & 1257 & $4.10 \pm 0.08 \mathrm{C}$ & $5.08 \pm 0.10 \mathrm{D}$ & $2.74 \pm 0.06 \mathrm{C}$ \\
\hline Topred & $13.82 \pm 0.99 \mathrm{AB}$ & $761.44 \pm 38.57 \mathrm{~B}$ & 186 & 1254 & $4.48 \pm 0.06 \mathrm{~B}$ & $5.42 \pm 0.10 \mathrm{C}$ & $2.97 \pm 0.06 \mathrm{~B}$ \\
\hline
\end{tabular}

* Within columns, means followed by the same letter are not significantly different $(\mathrm{P}<0.05)$ 

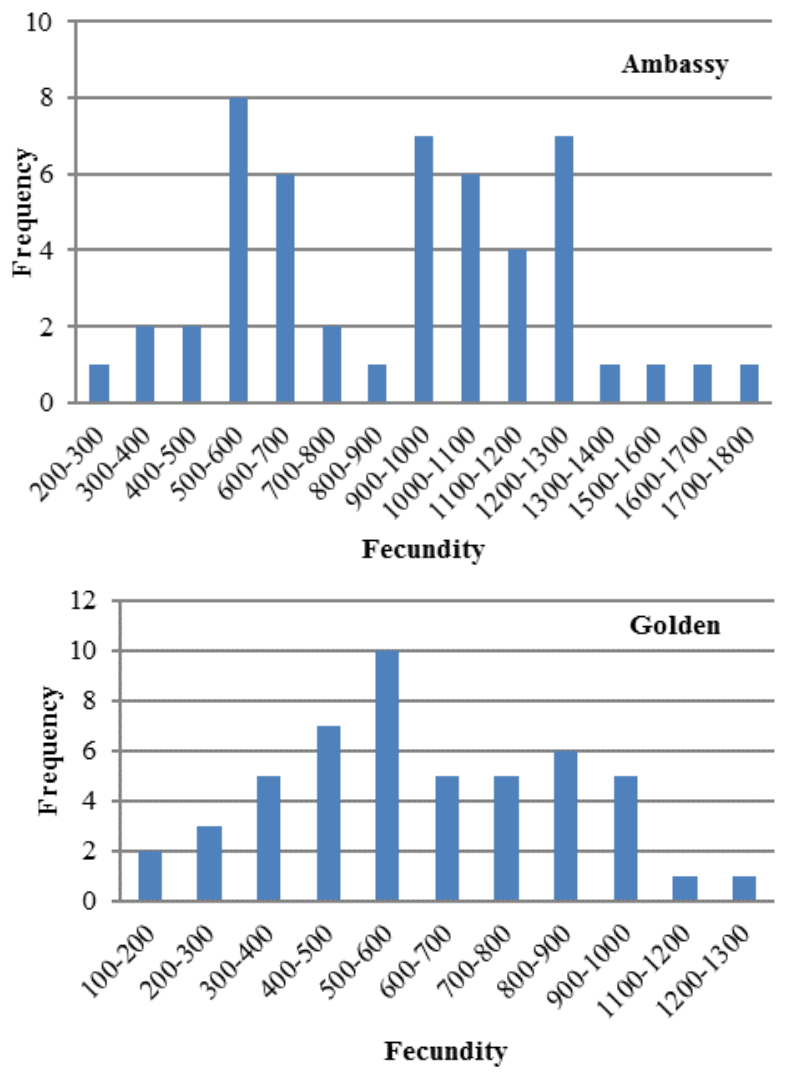
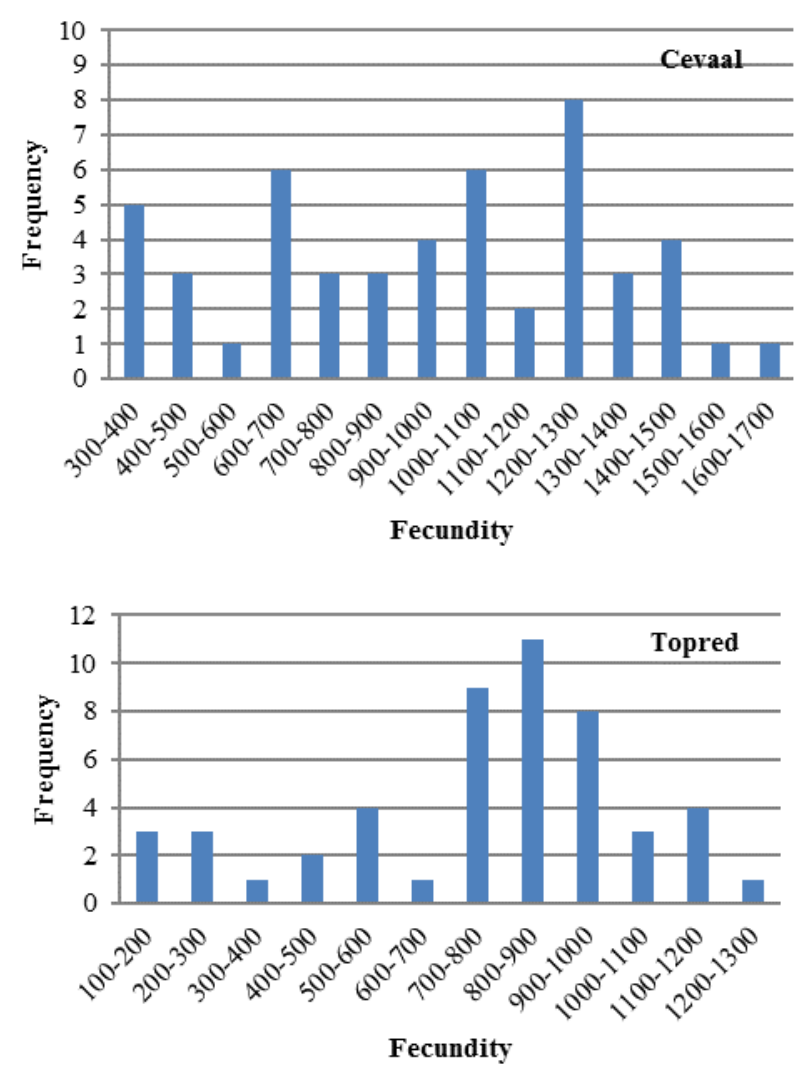

Figure 1. Frequency distribution for fecundity of Palaeolecanium bituberculatum on different apple cultivars.

$(\mathrm{P}<0.05)$. Furthermore, the differences between fecundity in Topred and Golden were significant $(\mathrm{P}<0.05)$ (Table 1).

Similar results with fecundity were obtained for body size parameters. The descending order of width, length and height was; Cevaal, Ambassy, Topred and Golden. There was no significant difference between Ambassy and Topred with respect to width and height $(\mathrm{P}<0.05)$, but significant differences were observed in body size parameters of other cultivars $(\mathrm{P}<0.05)$ (Table 1). Regardless of the apple cultivar, the width of the female scale ranged between $4.10-4.98 \mathrm{~mm}$, length ranged between $5.08-6.16 \mathrm{~mm}$ and height ranged between 2.74-3.34 $\mathrm{mm}$. Consequently, it was observed that as the female body size increases, the number of eggs laid by female increased too.

Relationship between fecundity and body size of $P$. bituberculatum: When apple cultivars were not taken into consideration, the correlation coefficient for the body width, length and height-fecundity were respectively calculated as $r^{2}=0.617, r^{2}=0.630$ and $r^{2}=0.733$. Multiple regression for female scale width, length, height-fecundity, the correlation coefficient was $r^{2}=0.830$. The regression equations for body size parameters and fecundity were provided in Table 2. Hence, the most effective factor on estimation of fecundity was identified as height and followed by length and width, respectively. The highest value for estimation of fecundity was reached when all three parameters evaluated together and multiple regression was conducted.

When all cultivars evaluated in itself to prevent the possible variations derived from the apple cultivars, similar results were obtained from the regression between fecundity and body size. The results indicate that the height of the female scale was closely correlated with fecundity. When all three

Table 2. Relationship between the body size and fecundity of Palaeolecanium bituberculatum.

\begin{tabular}{lcccc}
\hline Body size & $\mathbf{n}$ & Regression equation & $\mathbf{r}^{2}$ & $\mathbf{F}_{(\mathbf{1}, \mathbf{1 9 8})}$ \\
\hline Width & 200 & $\mathrm{y}=441.18 \mathrm{x}-1206.4$ & 0.617 & $319.431(\mathrm{p}<0.01)$ \\
Length & 200 & $\mathrm{y}=329.76 \mathrm{x}-1050.2$ & 0.630 & $338.318(\mathrm{p}<0.01)$ \\
Height & 200 & $\mathrm{y}=555.98 \mathrm{x}-884.15$ & 0.733 & $544.240 ; \mathrm{p}<0.01)$ \\
Width, Length, Height & 200 & Fecundity $=-1415.029+153.117$ & 0,830 & $\left(\mathrm{~F}_{(3,196)}=315.618 ;\right.$ \\
(W = Width, L= Length, H= Height) & & W+ 87.294 L + 339.128 H & & $\mathrm{p}<0.01)$ \\
\hline
\end{tabular}


parameters (width, length and height) evaluated together in order to estimate the fecundity, the correlation coefficient was higher than when all three parameters evaluated separately and correlation coefficient was observed as 0.809, 0.831, 0.901 and 0.835 for Ambasy, Cevaal, Golden and Topred, respectively. When the correlation between fecundity and body size evaluated separately depending on apple cultivars, the regression coefficient was found to be higher than combined assessments.

Table 3. Relationship between the body size and fecundity of Palaeolecanium bituberculatum on different apple cultivars $(n=50$ for each parameter).

\begin{tabular}{llcc}
\hline $\begin{array}{l}\text { Apple } \\
\text { cultivars }\end{array}$ & Body size & $\mathbf{r}^{\mathbf{2}}$ & $\begin{array}{c}\text { Width, length, } \\
\text { height }\left(\mathbf{r}^{\mathbf{2}}\right)\end{array}$ \\
\hline Ambassy & Width & 0.5221 & 0.809 \\
& Length & 0.5729 & \\
Cevaal & Height & 0.7012 & \\
& Width & 0.6355 & 0.831 \\
& Length & 0.5724 & \\
Golden & Height & 0.6610 & \\
& Width & 0.6749 & 0.901 \\
& Length & 0.6547 & \\
Topred & Height & 0.7739 & \\
& Width & 0.5532 & 0.835 \\
& Length & 0.5865 & \\
\hline
\end{tabular}

Relationship between population density and fecundity: So as to determine the population density, among 1250 apple trees in orchard, 10 trees from each of four apple cultivars were sampled randomly. The population densities on Ambassy, Cevaal, Golden and Topred cultivars were respectively observed as $12.03 \pm 0.87,6.36 \pm 0.33,16.51 \pm 0.94$ and $13.82 \pm 0.99$ adult insect/20 $\mathrm{cm}$ branch. While the differences between Golden and Cevaal were found to be significant $(\mathrm{P}<0.05)$, there was no significant difference between the others $(\mathrm{P}<0.05)$. For each apple cultivar, the correlation coefficient for average population densityfecundity was calculated as $r^{2}=0.831$, however, due to the low absolute frequency, there was no significant relation between population density and fecundity $[\mathrm{F}(1,2)=9.852, \mathrm{p}=0.088)]$. Nevertheless, it was remarkable that the average fecundity was the highest on apple cultivar with the least population density and the least on apple cultivar with the highest population density.

Relationship between fecundity and egg size of Palaeolecanium bituberculatum: The mean fecundity of 20 females which were selected for egg measurements was $869.05 \pm 82.72$, mean egg width was $0.2537 \pm 0.0000$ and mean egg length was $0.4574 \pm 0.019$. As a result of the regression analysis, it was determined that the correlation between fecundity and egg width $\left[\mathrm{F}(1,19)=4.220, \mathrm{r}^{2}=0.190, \mathrm{p}=\right.$ $0.055]$ and egg length $\left[F(1,19)=0.392, r^{2}=0.021, p=0.539\right]$ was just coincidental (Figure 2). In other words, there are no significant difference between the egg sizes (width, length) of the females which have different fecundity $(\mathrm{P}<0.05)$. The correlations between egg width-Bituberculate scale width, length, height $\left(\mathrm{r}^{2}=0.244, \mathrm{~F}(3,16)=1.720, \mathrm{P}=0.203\right)$ and between egg length- Bituberculate scale width, length, height $\left(r^{2}=0.009, F(3,16)=0.047, P=0.986\right)$ were not significant.

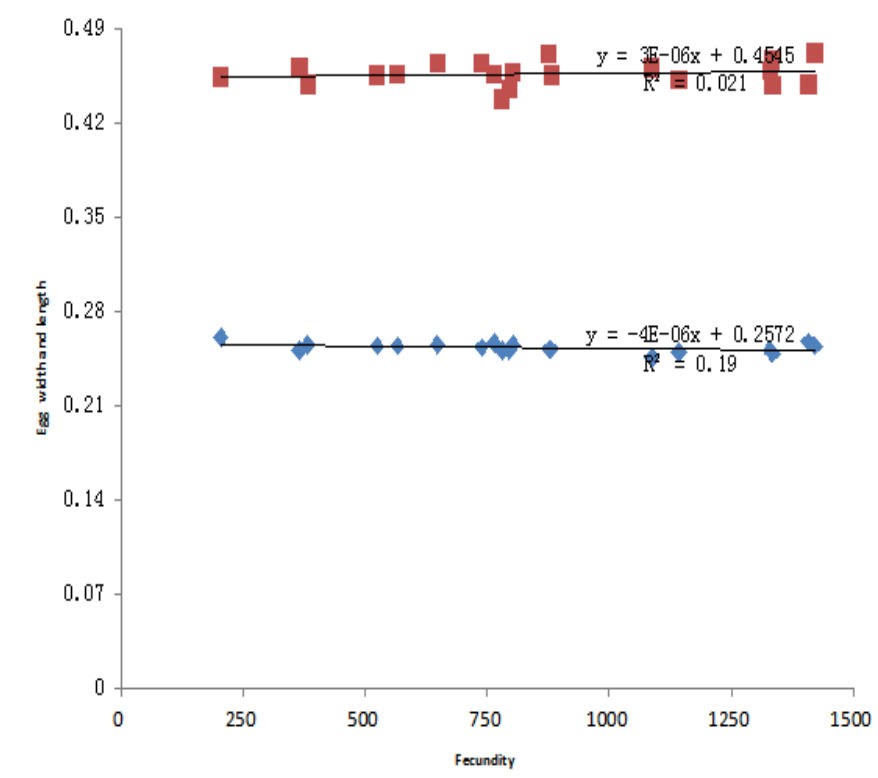

Figure 2. Relationship between fecundity and egg size of Palaeolecanium bituberculatum.

\section{DISCUSSION}

Results of the study indicated that the fecundity of Bituberculate scale varied between apple cultivars. When the difference between the fecundity was compared, no significant difference was observed between Cevaal and Ambassy $(\mathrm{P}<0.05)$ but the others were significant $(\mathrm{P}<0.05)$. The maximum mean fecundity by an individual female of Bituberculate scale was recorded on Cevaal with 956.34 \pm 51.44 (317-1622) eggs and the least was on Golden with 613.22 \pm 35.79 (136-1257) eggs. The egg counts conducted in 200 females revealed that a female laid an average of $807.25 \pm 23.89$ eggs. An average of 1000 eggs were recorded by Goantsa (1966) in Moldova. Vashchinskaya (1969) indicated that number of eggs varied between 404.6470.3 on different apple cultivars, İren and Okul (1974) determined that female produced at least 310, maximum 1005 and an average of 663.5 eggs. Okul et al. (1987) reported that female of Bituberculate scale laid 646 \pm 46.008 eggs (1811310) on apple trees on the first year and 671 \pm 51.772 eggs (288-1253) on the second year. Erol and Yaşar (1999) determined that a female laid an average of 259 eggs (14-646) in a study which they were carried out in Van province. While the fecundity of Bitubeculate scale reported here is generally 
similar to that found by other researchers mentioned above, some were lower than the present study. The differences in fecundity is normal due to the fact that biotic and abiotic factors like food variety, climate conditions, population density and number of eggs obtained from bituberculate females collected from their natural habitats. Andreev and Kutinova (2004) reported that three species of scale insect had different population density on different apple cultivars and cultivars showed different resistance to infestation by scale insects. Field evaluations showed differences in the susceptibility of avocado cultivars to Protopulvinaria pyriformis (Cockerell) (Homoptera: Coccidae) and it was detected that females which had large scales produced more eggs (Meijer et al., 1989). Qin et al. (2011) studied the effects of four host plants on the biology of the mealybug Dysmicoccus neobrevipes (Hemiptera: Pseudoccocidae) in laboratory conditions and determined that fecundity was significantly varied on different host plants. Likewise, the effect of six host plant species on bionomics of the mango mealybug Rastrococcus iceryoides (Hemiptera: Pseudoccocidae) was studied in the greenhouse and the results illustrated that fecundity of the mealybug differed significantly among the host plants (Tanga et al., 2013). These studies showed that a higher fecundity occurred when insects fed on more favoured hosts than on less favoured or resistant varieties.

The difference between the cultivars may indicate the differences in development performance of $P$. bituberculatum on these cultivars. On the other hand, such a conclusion may mislead without knowing the initial population of each cultivar in the orchard based on data obtained from unchecked and natural conditions. The maximum fecundity was observed on Cevaal with the least population density and least fecundity was observed on Golden with the highest population density. Such findings suggested that there could be a relationship between fecundity and population density. The correlation coefficient between population density and fecundity was $r^{2}=0.831$, however, the correlation was not found to be significant due to insufficient replication.

Insect herbivores can increase fecundity by increasing adult female body size (length or mass). In scale insects, adult female body size can influence the fecundity and often it can be affected directly by the host plant quality and insect population density (Simbiken, 2014). When the correlation between cultivars evaluated depending on female body size (width, length, height), there was no correlation between Ambassy and Topred with regard to width and height $(\mathrm{P}<0.05)$, but the others were significant $(\mathrm{P}<0.05)$. The differences between female scale length of all four cultivar were significant $(\mathrm{P}<0.05)$. The analyses to determine the relations between body size and fecundity revealed the highest correlation between height and fecundity $\left(\mathrm{r}^{2}=\right.$ 0.7332 ). In other words, it was determined that height was $73.3 \%$ effective on the estimation of fecundity and followed by length $\left(r^{2}=0.6308\right)$ and width $\left(r^{2}=0.6173\right)$, respectively. The highest value was reached when multiple regression was conducted between all three parameters and fecundity. In other words, width, length and height were $83.0 \%$ effective on the estimation of fecundity. When the correlation between fecundity and body size evaluated separately depending on apple cultivars, it was established that the correlation between fecundity and body size (width, length, height) was positive $(\mathrm{P}<0.05)$, the regression coefficient ranged between $\left(\mathrm{r}^{2}\right)$ $=0.809-0.901$. Speight (1994) reported that adult females of Pulvinaria regalis Canard (Homoptera: Coccidae) at oviposition were bigger in size when they were in low density populations than those in high densities. Such a case indicate that because of intraspecific competition in the nymphal stage, larger females were more fecund and produced larger eggs than smaller females and the adult size-fecundity relationship was of sigmoid form and there was no difference between host tree species depending on reproductive potential. Lo (1995) investigated Ceroplastes destructor and C. sinensis (Hemiptera: Coccidae) which were sampled in citrus orchards to determine their size, fecundity and observed significant correlations between fecundity and size $\left(r^{2}=0.83-\right.$ 0.90 , respectively) in both scale and reported that both the size and density of adults need to be measured to estimate egg production. Ben-Dov (1970) and Schneider et al. (1987) concluded that the volume of the Ceroplastes floridensis (Hormoptera: Coccidae) scale was influenced by the host nutritional value and population density and reported a strong correlation between scale volume and fecundity and a negative correlation between population density- scale body size and fecundity. Wakgari and Giliomee (1999) determined that size (width and length) and fecundity of Ceroplastes destructor on two different hosts were positively correlated $\left(r^{2}=0.84\right.$ and $\left.r^{2}=0.77\right)$ and also reported that the width and length of the female scale varied between hosts. Washburn et al. (1985) performed laboratory tests on Pulvinariella mesembryanthemi (Vallot) and reported that scale body size and fecundity were inversely related to density, indicating intraspecific competition. Loch and Zalucki (1997) indicated that adult fecundity correlated significantly but weakly with adult length and its variance decreased weakly with increasing density. The morphometric studies showed that the body size of $R$. iceryoides was greatly influenced by the host plant type on which the mealybug was reared. Adult female body length and width were significantly varied on different host plants (Tanga et al., 2013). Ong et al. (2014) revealed that the fecundity of yellow lac scale, Tachardina aurantiaca (Hemiptera: Kerriidae) increased remarkably with increase in female body size with $\mathrm{r}^{2}=0.59(\mathrm{p}<0.05)$ and larger sized female produced significantly more crawlers (F1,98 $=141.41$, $\mathrm{p}<0.05)$. Similar results were obtained between the adult size and fecundity in other similar studies. Lots of studies were carried out in many insect species from different order and family and it was determined that fecundity was positively 
correlated with adult size (Honek, 1993; Garcia-Barros, 2000; Logan et al., 2001; Jimenez-Perez and Villa-Ayala, 2006; Riddick, 2006).

In the present study, similar to results above, it was determined that there was a positive correlation between body size of female scale and fecundity. It was concluded herein that when the data were evaluated separately according to the cultivars, the relation between female body size and fecundity could be estimated more accurately.

In this study, the relation between fecundity and egg size (width and length) of $P$. bituberculatum was also investigated and it was determined that the size of the egg was not influenced by fecundity, indicating no reduction in quality of eggs produced by female insect depending on the increase or decrease in number of eggs. Similarly, it was found in this study that the egg size was not influenced by female body size and the regression between fecundity-egg size and between female body size- egg size was not significant.

Conclusion: These results revealed that; the fecundity was varied among cultivars, however, when comparing different species and varieties the fecundity and population density need to be evaluated together, the fecundity decreased with increasing population density and a positive correlation between fecundity and female body size, the independent of egg size from female body size and fecundity was observed in $P$. bituberculatum.

\section{REFERENCES}

Andreev, R. and H. Kutinova. 2004. Resistance to aphids and scale insects in nine apple cultivars. J. Fruit Ornam. Plant Res. 12:215-221.

Anonymous. 1995. T.C. Tarım ve Köy İşleri Bakanlığı Koruma ve Kontrol Genel Müdürlüğü Zirai Mücadele Teknik Talimatları Cilt 3, Ankara.

Ben-Dov, Y. 1970. A redescription of the Florida wax scale Ceroplastes floridensis Comstock (Homoptera: Coccidae). J. Entomol. Soc. South. Afr. 33:273-277.

Erol, T. and B. Yaşar. 1996. Van ili elma bahçelerinde bulunan zararlı türler ile doğal düşmanları. Türkiye Entomoloji Dergisi. 20:281-293.

Erol, T. and B. Yaşar. 1999. Van ili elma ağaçlarında zararlı Lepidosaphes ulmi (L.) (Homoptera, Diaspididae) ile Palaeolecanium bituberculatum (Targ. and Tozz.) (Homoptera, Coccidae)'un populasyon degişimleri, bazı biyolojik ozellikleri ve dogal düşmanları üzerinde araştırmalar. Tr. J. of Agric. Forest. 23:151-164.

Garcia-Barros, E. 2000. Body size, egg size and their interspecific releationships with ecological and life history traits in butterflies (Lepidoptera: Papilionoidea, Hesperioidea). Biol. J. Linnean Soc. 70:251-284.

Goantsa, I.K. 1966. The parasites of the Bituberculate soft scale (Palaeolecanium bituberculatum Targ.) and the
Spherical Apple Soft Scale (Eulecanium mali Schr.) in the Moldavian SSR. (In Russian). Trudy Moldav. Nauchno - Issled. Inst. Sadov. Vinogr. Vinod.13:59-69.

Honek, A. 1993. Intraspecific variation in body size and fecundity in insects: a general releationship. OIKOS 66:483-492.

Iren, Z. and A. Okul. 1974. Kış ilaçlamaları ve Orta Anadoluda elma ağaçlarında zararlı (Palaeolecanium bituberculatum)'a karşı ilaçlı mücadele imkanlarının araştırılması. Bit. Kor. Bült. 14:29-42.

Jimenez-Perez, A. and P. Villa-Ayala. 2006. Size, fecundity and gonadic maturation of Toxotrypana curvicauda (Diptera: Tephritidae). Fla. Entomol. 89:194-198.

Kaydan, M.B., Ülgentürk, S. and L. Erkılıç. 2007. Türkiye' nin gözden geçirilmiş Coccoidea (Hemiptera) türeleri listesi. Yüzüncü Yıl Uni. Zir. Fak. Tar. Bil. Derg. 17:89106.

Kozár, F., M. Konstantinova, K. Akman, M. Altay and H. Kıroğlu. 1979. Distribution and density of scale insects (Homoptera: Coccidae) on fruit plants in Turkey in 1976. Acta Phytopathol. Acad. Sci. Hung. 14:535-542.

Kosztarab, M. and F. Kozar. 1988. Scale insects of central Europe. Dr. W. Junk Publishers, Boston, USA.

Lo, P.L. 1995. Size and fecundity of soft wax scale (Ceroplastes destructor) and Chinese wax scale $(C$. sinensis) (Hemiptera: Coccidae) on citrus. New Zeal. Entomol.18:63-69.

Lodos, N. 1986. Türkiye Entomolojisi. II. Basım. pg. 337338, İzmir.

Loch, A.D. and M.P. Zalucki. 1997. Variation in length, fecundity and survival of Pink Wax Scale, Ceroplastes rubens Maskell (Hemiptera: Coccidae), on Umbrella Trees. Aust. J. Zool. 45:399-407.

Logan, D.P., P.G. Allsopp and M.P. Zalucki. 2001. Effect of body size on fecundity of Childers canegrub, Antitrogus parvulus Britton (Coleoptera: Scarabaeidae). Aust. J. Entomol. 40:365-370.

Meijer, A.H. De M. Wysoki, E. Swirski, D. Blumberg and Y. Izhar. 1989. Susceptibility of avocado cultivars to the Pyriform Scale, Protopulvinaria pyriformis (Cockerell) (Homoptera: Coccidae). Agric. Ecosyst. Environ. 25:7582.

Okul, A., H. Bulut, and C. Zeki. 1987. Ankara ili elma agaçlarında zararlı bazı Coccoidea (Homoptera) türlerinin biyolojileri üzerine araştırmalar. Turkiye I. Entomoloji Kongresi Bildirileri. Entomoloji Dernegi. 3:109-118.

Ong, S. P., G. Neumann, Y. Khairun, M.C. Salmah and L.G. Kirton. 2014. Development and size-fecundity relationship of the yellow lac scale, Tachardina aurantiaca (Hemiptera: Sternorrhyncha: Kerriidae). J. Trop. Forest. Sci. 26:435-441.

Ozgokçe M.S. 1995. Van ili meyve ağaçlarında zarar yapan Coccoidea (Homoptera) üst familyasına bağlı türlerin 
yayılışları, konukçuları ve önemlilerinin populasyon dalgalanmaları uzerine araştırmalar. Yuk. Lis. tezi, Fen Bil. Enst. Van.

Ozgokçe, M.S. and B. Yaşar 1995. Elma agaçları uzerinde Lepidosaphes ulmi L. (Homoptera:Diaspididae) ve Palaeolecanium bituberculatum (Targ.-Tozz.) (Homoptera:Coccidae)' un populasyon dalgalanmalarına yoneylerin etkisi üzerine bir araştırma. Yüzüncü Y1l Üni. Zir. Fak. Derg. 5:163-174.

Ozgokçe, M.S., B. Yaşar, and İ. Karaca. 1999. Life tables of Lepidosaphes ulmi (L.) and Palaeolecanium bituberculatum (Targioni Tozzetti) (Hemiptera: Coccoidea) on apple trees in Van province. Turkey. Entomol. Bari. 33:317-322.

Pedigo, L.P. 1996. Entomology and pest management. Second Edition. Prentice-Hall Inc. NJ, USA.

Qin, Z., J. Wu, , B. L. Qiu, S. Ren and S. Ali. 2011. Effects of host plant on the development, survivorship and reproduction of Dysmicoccus neobrevipes Beardsley (Hemiptera: Pseudoccocidae). Crop Prot. 30:1124-1128.

Riddick, E.W. 2006. Egg load and body size of lab-cultured Cotesia marginiventris. Biocontrol 51:603-610.

Schneider, B., H. Podoler and D. Rosen. 1987. Population dynamics of the Florida wax scale, Ceroplastes floridensis (Hormoptera:Coccidae), on citrus in Israel. 4. Abundance. Acta Oecol. Oecologia Applicata. 8:217228.

Simbiken, N.A. 2014. Biology and ecology of grapevine scale Parthenolecanium persicae (Fabricius) and frosted scale Parthenolecanium pruinosum (Cocquillet)(Hemiptera: Coccidae) on Grapevines Vitis vinifera L. PhD Thesis. The Australian National University, Canberra, Australia.

Speight, M.R. 1994. Reproductive capacity of the horse chestnut scale insect, Pulvinaria regalis Canard (Hom., Coccidae). J. Appl. Entomol. 118:59-67.

Tanga, C.M., S. Ekesi, P. Govender and S.A. Mohamed. 2013. Effect of six host plant species on the life history and population growth parameters of Rastrococcus iceryoides (Hemiptera: Pseudococcidae). Fla. Entomol. 96:1030-1041.
Tuncer, C. and E. Ogur. 2009. The life history, natural enemies and spatial distribution of Palaeolecanium bituberculatum (Targ. And Tozz.) (Hom.: Coccidae) on apple trees. $6^{\text {th }}$ International Conference on Arthropods: Chemical, Biotechnological and Environmental Aspects. June 21-26, 2009. Ochotnica Dolna, Poland. Abstract Book p. 28.

Ulgentürk, S. and H. Çanakçıglu. 2004. Scale insect pests on ornamental plants in urban habitats in Turkey. J. Pest. Sci. 77:79-84.

Vashchinskaya, N.V. 1969. Some data on the binomics of the Hawthorn Scale Palaeolecanium bituberculatum (Targ.Tozz.) (Homoptera: Coccoidea) in the conditions of the Armenian SSR. Ent. Bozr. 48:745-751.

Vuruş, M. and F. Erler. 2004. The soft scale insect (Homoptera: Coccidae) species determined on ornamental plants in Antalya, Turkey. Proc. $10^{\text {th }}$ Int. Symp. on Scale Insect Studies. April 19-23, 2004. Adana, Turkey. p. 325

Wakgari, W.M. and J.H. Giliomee. 1999. Fecundity, size and dispersal of the White wax scale, Ceroplastes destructor (Hemiptera: Coccidae), in the Western Cape province of South Africa. Entomol. Bari. 33:365-375.

Washburn, J.O., W.F Gordon and J.K. Grace. 1985. Effects of density on survival, development and fecundity of the soft scale Pulvinariella mesembryanthemi (Homoptera: Coccidae) and its host plant. Environ. Entomol. 14:754 761.

Yigit, A. and N. Uygun. 1982. Adana, İçel ve Kahramanmaraş illeri elma bahçelerinde zararlı ve yararlı faunanın saptanması üzerinde çalışmalar. Bit. Kor. Bült. 22:163178.

Zeki, C., S. Ulgentürk, M.B. Kaydan, D. Ozmen and S. Toros. 2004. Records of scale insects (Hemiptera: Coccoidea) from orchards and neighbouring plants in provinces of Afyon, Ankara, Burdur, Isparta, Turkey. Proc. $10^{\text {th }}$ Int. Symp. on Scale Insect Studies. April 19-23, 2004. Adana, Turkey. 